\title{
UPAYA DINAS SOSIAL TERHADAP ORANG-ORANG BERKEBUTUHAN KHUSUS (DISABILITAS) DI KABUPATEN MERAUKE
}

\author{
Y. Budiman ${ }^{1}$, Farida Romaito Pohan ${ }^{2}$ dan Aminah ${ }^{3}$ \\ Administrasi Publik \\ Sekolah Tinggi Ilmu Administrasi Karya Dharma Merauke
}

\begin{abstract}
The objectives and scope of this research are, among others, to find out how the efforts of the social services in carrying out their duties in dealing with people with special needs (disabilities) and to find out what supporting and inhibiting factors are in the process of implementing Regent Regulation number 52 of 2016 article 13 paragraph (2). The research method used in this research is descriptive qualitative. The results of this study include: the rights of persons with disabilities are still not being considered such as education, housing worthiness, lack of social services, health including accessibility to disabled services. Based on the results of the research, it can be concluded that in an effort to empower persons with disabilities, the government, in this case the social service, has made several efforts, including: providing assistive devices, providing social assistance to each person with disabilities both inside and outside the institution, and the government providing opportunities for persons with disabilities to participate in banana chips making training in Malang as an effort to open their own business. Supporting factors in this study include family and community support and inhibiting factors, including the limited government budget to allocate funds for the provision and accessibility of disability aids.
\end{abstract}

Keywords: Social Service, People with special needs, Disabilities 


\section{Pendahuluan}

Indonesia dikenal sebagai negara hukum seperti yang tertera pada sila yang ke - 5 yang berbunyi keadilan sosial bagi seluruh rakyat Indonesia dan hal ini sesuai dengan Undang- undang Dasar 1945 dalam pasal 27 ayat 2, yakni "Setiap warga negara berhak atas pekerjaan dan penghidupan yang layak bagi kemanusiaan", demi untuk mengsejahterkan rakyatnya dengan tujuan untuk mencapai kemakmuran dan kesejahteraaan masyarakat, termasuk orang-orang berkebutuhan khusus (disabilitas), memberikan rehabilitasi untuk lansia, anak terlantar, bahkan untuk fakir miskin. Istilah penyandang disabilitas sering digunakan untuk menyebut sekelompok masyarakat yang memiliki gangguan mental, kelainan atau bahkan kehilangan fungsi organ tubuhnya. Penyandang disabilitas pada dasarnya bukanlah merupakan kaum minoritas dan wajib mendapatkan perhatian yang sama dengan masyarakat normal lainnya. Hak- hak penyandang disabilitas ditegaskan dalam Pasal 42 Undang- Undang Dasar No. 39 Tahun 1999 tentang Hak Asasi Manusia.

Para penyandang disabilitas di Kota Merauke khususnya masih menghadapi tantangan dalam memperoleh haknya. Selama ini hak para penyandang disabilitas belum secara khusus diperhatikan. Urusan kehidupan bermasyarakatpun pandangan masyarakat terhadap penyandang disabilitas juga belum memberikan ruang untuk menerima dan memahami arti dari keberadaan para penyandang disabilitas. Padahal aksesibilitas, ketersediaan sarana dan prasarana ramah bagi penyandang disabilitas. Masyarakat juga masih menganggap bahwa penyandang disabilitas adalah orang-orang yang tidak bisa melakukan apa- apa, membutuhkan bantuan dalam segala hal. Dunia kerja pun, sebagian besar masyarakat masih menganggap sebelah mata kemampuan penyandang disabilitas. Kebanyakan dalam dunia kerja dan pendidikan enggan untuk menerima seorang penyandang disabilitas sebagai karyawan dan siswa.

Masyarakat berasumsi bahwa seorang penyandang disabilitas tidak akan mampu melakukan pekerjaan seefektif seperti karyawan lain yang bukan penyandang disabilitas. Sehingga bagi para penyedia lapangan pekerjaan, memberikan pekerjaan untuk para penyandang disabilitas sama halnya dengan mendorong perusahaan dalam jurang kebangkrutan karena harus rela menyediakan beberapa alat-alat bantu bagi kemudahan para penyandang 
disabilitas dalam menunjang

aktivitasnya. Berdasarkan jumlah tersebut, rekapitulasi data dari Dinas Sosial pada tahun 2018 sampai tahun 2019 menunjukkan bahwa penyandang disabilitas terbanyak adalah terletak pada di dalam kota merauke. Satu tahun sekali dinas Sosial hanya mengirim 1 peserta saja untuk mengikuti pelatihan di luar papua. Apabila dibandingkan dengan jumlah keseluruhan penyandang disabilitas di Kota Merauke, jumlah penyandang disabilitas yang diberikan pelatihan keterampilan tersebut masih sangat minim. Pemerintah belum memiliki tempat penampungan yang khusus bagi penyandang disabilitas dan juga rendahnya tingkat pendidikan yang dimiliki sehingga, mempengaruhi kualitas lowongan perkerjaan mereka atau terbatasnya ketersedian perkerjaan bagi penyandang disabilitas.

Dampak yang terjadi yaitu peneliti masih menemukan orang, remaja atau warga yang menyandang disabilitas yang terlantar di pingir jalan (di depan kodim, mandala), suka menunggu orang yang datang untuk mengasihani dan memberikan uang ataupun makanan. Tujuan dan ruang lingkup dari penelitian ini antara lain untuk mengetahui bagaimana upaya dinas sosial dalam menjalankan tugas dalam menangani orang-orang berkebutuhan khusus (disabilitas) dan untuk mengetahui faktor pendukung dan penghambat apa saja dalam proses implementasi peraturan Bupati nomor 52 tahun 2016 pasal 13 ayat (2).

\section{Metode Penelitian}

Penelitian yang digunakan oleh peneliti adalah deskriptif kualitatif. Penelitian deskriptif memberikan gambaran secara sistimatis faktual dan akurat dari objek yang di teliti sehingga mendapatkan hasil yang secara benar. Penelitian di sajikan deskripsi secara narasi dengan mengambil data- data yang sudah didapat dari informan yang ada di dalam instansi terkait atau Dinas Sosial. Peneliti menggunakan penelitian kualitatif karena permasalahan yang di bahas dalam penelitian ini tidak berkenaan dengan angka- angka, tetapi mendeskrepsikan, menguraikan, dan menggambarkan tentang Upaya dinas sosial terhadap orang- orang berkebutuhan khusus (Disabilitas).

Tempat penelitian ini yaitu pada Kantor Dinas Sosial Merauke yang terletak di Jalan R.E Martadinata dan penelitian ini di laksanakan selama 3 bulan. Penelitian memiliki dua sumber darra yaitu sumber data primer dna sumber data sekunder. Data primer adalah data yang didapat dari pelaku 
utama dari objek yang diteliti. Sumber data primer dari penelitian ini adalah Sekretaris Dinas Sosial, Kepala bidang yang bertanggung jawab dalam penanganan disabilitas, kepala panti asuhan St. Vinsentius, dan anggota keluarga yang memiliki penyandang disabilitas di dalamnya. Data sekunder adalah data tambahan yang berupa informasi untuk melengkapi data perimer. Data sekunder dalam penelitian ini adalah dokumen dan arsip dari Intansi Dinas Sosial yang berhubungan dengan penelitian. Data- data tersebut antara lain data jumlah pegawai dan data jumlah penyandang disabilitas.

\section{Hasil dan Pembahasan}

Penyandang Disabilitas adalah setiap orang yang mempunyai kelainan fisik dan/atau mental, yang dapat mengganggu atau merupakan rintangan dan hambatan bagi mereka untuk melakukan kegiatan secara selayaknya. Di kabupaten merauke jumlah penyandang Disabilitas tidak begitu banyak dan sangat minim jumblahnya, yaitu sekitar \pm 38 orang untuk penyandang yang disabilitas yang berada di luar panti atau di dalam naungan dinas sosial, sedangkan yang didalam panti terdapat 30 orang, yaitu jumblah penyandang disabilitas di kabupaten merauke sebanyak 68 orang. Berikut adalah jumlah penyandang disabilitas yang berada di luar/ ataupun di dalam panti.

Tabel 1.

\section{Penyandang Disabilitas di Luar Panti}

\begin{tabular}{|l|l|l|}
\hline No & \multicolumn{1}{|c|}{ Distrik } & Jumlah \\
\hline 1. & Merauke & 28 jiwa \\
\hline 2. & Semangga & 5 jiwa \\
\hline 3. & Jagebob & 4 jiwa \\
\hline 4. & Kurik & 1 jiwa \\
\hline
\end{tabular}

Tabel 2.

\section{Penyandang Disabilitas di Dalam Panti}

\begin{tabular}{|l|l|l|}
\hline No & $\begin{array}{l}\text { Jenis penyandang } \\
\text { disabilitas }\end{array}$ & Jumlah \\
\hline 1. & Tuna Netra & 6 orang \\
\hline 2. & Tuna Runggu/ tuli & 5 orang \\
\hline 3. & Tuna wicara/ bisu & orang \\
\hline 4. & $\begin{array}{l}\text { Tuna runggu dan } \\
\text { wicara }\end{array}$ & orang \\
\hline 5. & Cacat anggota gerak & orang \\
\hline 6. & Lumpuh & orang \\
\hline 7. & Cacat mental & orang \\
\hline
\end{tabular}


Berdasarkan peraturan Bupati nomor 52 tahun 2016 pemerintah dalam hal ini dinas sosial memiliki tugas dalam upaya penanganan orang-orang berkebutuhan khusus (Disabilitas) antara lain rehabilitasi sosial anak dan lanjut usia, penyandang disabilitas diluar atau lembaga, pelayanan tuna wisma dan fakir miskin, dan rehabiltas sosial dan korban perdagangan orang.

Hasil penelitian yang didapatkan berdasarkan peraturan tersebut antara lain:

\section{Upaya dinas soisal dalam pemberdayaan penyandang} disabilitas

Dalam pelaksanaannya dinas sosial memiliki peran aktif dalam pemberdayaan penyandang disabilitas. Dinas sosial adalah salah satu instansi pemerintah yang menangani masalah sosial dalam masyarakat. Sebagai salah satu contoh adalah upaya dinas sosial dalam penanganan penyandang disabilitas. Di dalam dinas sosial memiliki bidang rehabilitas sosial dan penanganan fakir miskin yang memiliki tugas pokok dan fungsi yaitu:

a. Rehabilitas sosial anak dan lanjut usia

Rehabilitas sosial ialah suatu proses perbaikan ataupun penyembuhan dari kondisi yang tidak normal menjadi normal. Didalam kota merauke masih kerap kali di temukan anak- anak jalanan yang pada saat jam sekolah justru mereka menjadi tukang parkir di beberapa tempat swalayan yang ada di kota merauke. Rehabilitas lanjut usia juga, kerap kali di temukan bahkan jumblahnya lebih banyak bagi mereka yang tinggal di bagian pedesaan atau daerah terpencil yang jaraknya jauh dari kota. Mereka adalah orang- orang yang minim mendapatkan fasilitas dari pemerintah yang menuntut untuk mendapatkan perhatian dari pemerintah yang menangani hal ini, khususnya dinas sosial.

Dari hasil wawancara dan observasi yang dilakukan oleh peneliti, dapat di simpulkan dinas sosial belum mengoptimalkan kinerjanya, karena kerap kali anak maupun lansia masih belum mendapatkan kebijakan dari pemerintah.

b. Penyandang disabilitas di luar panti dan lembaga

Dalam penanganannya Dinas Sosial menangani penyandang disabilitas baik yang di dalam panti maupun di luar panti.

\section{(a) Luar Panti}

Penyandang Disabilitas beberapa orang tidak mengiginkan untuk tinggal di dalam panti baik dari ke inginannya 
sendiri maupun dari pihak keluarga, disini peran dinas sosial untuk menangani penyandang Disabilitas di luar panti yaitu dengan memberikan bantun- bantuan tiap tahunnya kepada penyandang Disabilitas, seperti tongkat, kursi roda, alat pendengar dan sembakau, tergantung dari tingakat kebutuhan yang mereka butuhkan.

Di dalam dinas sosial memiliki data penyandang disabilitas kurang lebih \pm 38 orang, yang di antaranya terdapat di Distrik Merauke sebanyak 28 orang, Distrik semangga 5 orang, Distrik jagebob 4 orang dan Distrik kurik 1 orang.

\section{(b) Dalam Panti}

Dinas sosial dalam upayanya juga menangani penyandang disabilitas yang berada di dalam panti, salah satunya adalah panti asuhan Alma, yang mana di dalam panti ini, bukan hanya menangani penyandang Disabilitas, namun ada juga yang mengalami cacat ringan, cacat sedang dan cacat berat.

\section{c. Pelayanan tuna wisma dan}

\section{fakir miskin}

Hasil wawancara dan observasi peneliti terhadap pegawai dinas sosial yaitu sebagai berikut:

"Pada tuna wisma dan fakir miskin di kabupaten merauke belum ada, sebagian besar masyarakat yang yang hidup di kota yang tidak memiliki rumah pribadi mereka hidup dengan cara mengekos $d$ rumah rumah kos yang ada di perkotaan".

Dari wawancara di atas dapat di simpulkan bahwa, jika terdapat tuna wisma dan faki miskin dinas sosial akan memberikan kebijakan- kebijakan yang berkaitan mengenai hal tersebut.

\section{d. Rehabilitas sosial dan korban perdagangan orang.}

Dinas sosial mempunyai program melaksanakan rehabilitasi di bidang sosial, misalnya pengobatan cek gula darah gratis untuk masyarakat yang rumahnya jauh dari kota. Dengan adanya Rehabilitasi sosial di harapkan dinas sosial mampu meningkatkan masyarakat dalam kemampuan bersosialisasi atau mampu memberikan perubahan lebih baik kedepannya di bandingkan kondisi sebelumnya.

Hasil wawancara dan observasi peneliti kepada bapak S, mengemukakan bahwa, "di kabupaten merauke belum pernah ada kasus mengenai perdagangan orang, jadi dinas sosial belum pernah menangani hal tersebut".

Dari hasil wawancara di atas dapat di simpulkan bahwa, dinas sosial dalam hal ini telah menjalankan tugasnya dengan baik, walaupun dalam penanganannya belum ada korban, 
namun dina sosial tetap menyediakan, jika sewaktu- waktu akan ada korban.

Dari hasil penjabaran di atas dapat di simpulkan bahwa, dinas sosial sangat bertanggung jawab dalam pengupayaan yang menjadi tanggung jawab dari dinas sosial, meskipun ada beberapa ketidak puasan masyarakat dalam pelaksanaan dinas sosial tetapi dalam hal ini dinas sosial telah memberikan yang terbaik.

\section{e. Penanganan Dinas Sosial \\ Dalam menjalankan tugasnya} dinas sosial selaku dinas yang menaungi mengenai masalah kesejahteraan sosial, memberikan kesempatan juga kepada penyandang disabilitas yang berada di dalam panti, salah satu upayanya yaitu dinas sosial memberikan kesempatan kepada penyandang disabilitas untuk dapat di berangkatkan di luar kota (malang), guna untuk mengikuti pelatihan pembuatan keripik pisang, sehingga dari pelatihan tersebut di harapakan anak- anak penyandang disabilitas selain dapat melatih kemandirian dapat juga memiliki potensi yang nanatinya dapat di gunakan sebagai alat memperoleh rezeki.

Dapat disimpulkan bahwa peraturan bupati nomor 52 tahun 2016 sudah di jalankan dengan baik namun masih dengan adanya beberapa faktor pendukung dan juga masih mengalami beberapa hambatan antara lain :

2. Faktor pendukung dan Faktor penghambat dalam pelaksanaan pemenuhan penyandang Disabilitas

\section{a. Faktor Pendukung}

Faktor pendukung adalah faktor yang memberi pengaruh positif terhadap jalannya upaya Dinas Sosial terhadap penyandang Disabilitas. faktor- faktor tersebut terdiri dari:

(a) Adanya regulasi peraturan bupati nomor 52 tahun 2016 tentang organisasi dan tata kerja dinas sosial.

Dalam mendukung pemberdayaan penyandang disabilitas, maka di buatkan aturan mengenai rehabilitas disabilitas, guna untuk mensosialisasikan penyandang disabilitas di kabupaten merauke, melalui dinas sosial.

\section{(b) Dukungan dari keluarga}

Dimana dukungan keluarga sangat mendukung dalam pemberdayaan penyandang Disabilitas, baik dalam benyuk kesejahteraan penyandang disabilitas maupun pemulihan dalam diri penyandang disabilitas. Peran keluarga sangat di harapkan pemerintah dalam pemenuhan peyandang Disabilitas. Hasil wawancara dengan bapak Siswo selaku sekretaris Dinas sosial, mengatakan bahwa; 
'peran keluarga sangat memberikan dampak yang positif terhadap penyandang disabilitas, jika sang keluarga salah mendidik atau mengajarkan maka dampaknya akan buruk, jika Ia seorang anak, maka akan mempengaruhi tumbuh kembangnya, seperti penyandang yang berada di depan kodim mandala, beliau di tuntut oleh keluarganya agar dapat juga menghasilkan uang, walaupun hanya bermodalkan belas kasihan dari orang'.

\section{(c) Dukungan Masyarakat}

Dukungan masyarakat setempat juga sangat di harapkan oleh pihak pemerintah demi untuk mendukung perkembangan penyandang Disabilitas. Karna seperti yang kita ketahui bahwa banyak dari kalangan masyarakat yang kurang menerima penyandang disabilitas hidup di antara mereka, karna faktor tersebut penyandang disabilitas memiliki kesempatan yang minim dalam memperoleh perkerjaan.

(d) Tersedianya sumber daya manusia yang memadai dalam penanganan penyandang disabilitas.

Dalam mendukung program yang di berikan oleh pemerintah mengenai rehabilitas penyandang disabilitas masih mengalami kurangnya anggota dalam penanganan disabilitas, karena ada juga pegawai yang menjabat di bagian kasubag umum namun juga menangani penyandang disabilitas, sehingga mempengaruhi kinerja dalam suatu perkerjaan menjadi kurang efisien dalam pengimplementasiannya.

(e) Sarana dan Prasarana yang memadai.

Dalam melakukan pemberdayaan penyandang Disabilitas faktor sarana dan prasara yang memadai sangat mendukung tercapainya tujuan mengenai kesejahteraan penyandang Disabilitas. Dari hasil wawancara peneliti dengan Suster Florensia, yang menangani penyandang Disabilitas mengemukakan bahwa; 'mereka penyandang Disabilitas sangat mengalami hambatan dalam memperoleh haknya sebagai warga negara, di mana mereka selain dikucilkan oleh masyarakat mereka juga kerapkali merasa bahwa pemerintah kurang memperhatikan mereka, contohnya adalah keterbatasan sarana dan prasarana penyandang disabilitas di dalam panti, sehingga suster para perawat penyandang Disabilitas mencari mitra sendiri, dan turun dengan membawa berkas mengenai penyandang Disabilitas, dengan tujuan mengharapkan mendapatkan mitra atau perusahaan yang ingin membantu.

b. Faktor Penghambat 
Ada beberapa hambatan dalam pelaksanaan Rehabilitasi Sosial penyandang Disabilitas yaitu sebagai berikut:

\section{(a) Belum adanya tempat rehabilitasi sosial}

Hal ini lah yang menjadi salah satu kendala dalam hal penanganan penyandang disabilitas. Jika pemerintah memiliki tempat rehabilitas sosial penyandang disabilitas maka, pastinya akan dapat memberikan peluang bagi penyandang di sabilitas dapat di terima atas keberadaannya, serta mampu menjadikan penyandang disabilitas menjadi anak- anak yang memiliki potensi dan bakat yang ada pada diri mereka sendiri.

\section{(b) Kurangnya sosialisasi kepada masyarakat}

Dalam upaya dinas sosial untuk dapat menyelesaikan permasalahan penyandang disabilitas, tentunya tidak hanya terletak pada aparaturnya saja tetapi di butuhkan partisipasi dan perhatian masyarakat. Karena masyarakat menjadi objek utama dari penanganan disabilitas, jika masyarakat mampu menerima penyandang disabilitas dalam berkehidupan bermasyarakat maka penyandang disabilitas akan merasa di hargai oleh orang lain, sehingga dampaknya akan memberikan perubahan fisik maupun metal penyandang disabilitas dalam kehidupannya.

Dari hasil wawancara dan observasi peneliti kepada bapak $\mathrm{R}$ bahwa:

"itu yang menjadi kendala bagi kami, karena kami belum melakukan sosialisasi terhadap masyarakat mengenai penyandang disabilitas:

Dari hasil wawancara dan observasi peniliti di atas, bahwa dapat di simpulkan dinas sosial dalam hal ini belum mengoptimalkan kinerjanya, karena masih di temukan masyarakat yang tidak mengetahui mengenai hal- hal pokok yang di berikan dinas sosial terhadap penyandang disabilitas, sehingga jika penyandnag disabilitas berada ditenggah- tengah masyarakat, mereka hanya menjadi objek bully bagi anak sebayanya maupun masyarakat yang kurang dalam hal pengetahuannya.

\section{(c) Kerjasama Dinas sosial dengan lembaga lain.}

Dinas sosial belum atau tidak memiliki mitra lain dalam penanganan penyandang disabilitas, sedangkan Kerjasama merupakan hal yang sangat penting bagi kehidupan manusia karena manusia adalah mahluk sosial yang saling membutuhkan antara yang satu dan yang lainnya. 
Hasil wawancara dan observasi peneliti terhadap sekretaris pegawai dinas sosial, yaitu sebagai berikut:

"sejauh ini dinas sosial tidak memiliki mitra- mitra lain yang turut membantu dalam pemberdayaan penyandang disabilitas, hal itu juga yang menjadi hambatan bagi kami, sehingga penyandang disabilitas kebutuhannya tidak dapat sepenuhnya dapat terwujud, misalnya dalam hal pendidikan, namun hal tersebut tidak menuntut kemungkinan bahwa kami tidak mengupayakan, kami akan tetap mengupayakan demi untuk mereka yang penyandang disabilitas".

Dari hasil wawancara dan observasi peniliti di atas, bahwa dapat di simpulkan dinas sosial dalam hal ini sudah mengupayakan semampu mereka, walaupun dalam hal anggaran mereka masih minim di karena kan dinas sosial tidak memiliki mitra lain yang mampu memberikan anggaran kepada mereka, itu sebabnya dinas sosial masih memiliki kendala dalam pengoptimalisasian anggaran, yang memberi dampak kepada penyandang disabilitas.

Sebagai harapan peneliti semoga penyandang disabilitas dapat dihargai di kalangan masyarakat walaupun berbanding terbalik dengan harapan. Banyak dari masyarakat yang merasa di rugikan jika mereka memperkerjakan penyandang Disabilitas, bahkan mereka mengatakan penyandang Disabilitas adalah orang yang sakit, sehingga mereka tidak dapat berkerja. Dinas sosial selaku penanggung jawab dalam bidang pengayoman masyarakat, di nilai kurang produktif dalam membimbing penyandang Disabilitas karena selama ini aparat dari bidang Disabilitas mereka hanya memberikan bantuan berupa halhal pokok yang di butuhkan oleh penyandang Disabilitas seperti uang dan pakaian.

Sedangkan di sini yang sangat di butuhkan sekali oleh penyandang Disabilitas yaitu sebuah lapangan perkerjaan di mana lapangan perkerjaan dapat mempengaruhi perubahan struktur kehidupan, dan jika sewaktuwaktu pemerintah tidak memberikan bantuan lagi terhadap penyandang Disabilitas, setidaknya mereka jadi memiliki penghasilan sendiri dengan kemampuan yang di kuasai, dan tanpa ada kehidupan yang ketergantungan oleh pihak terkait. Sebagai saran Misalnya pihak terkait memberikan pelatihan menjahit, kreatif mendaur ulang sampah, atau dengan cara- cara yang lebih kreatif lainnya. Sehingga dimana penyandang Disabilitas tidak merasa sedang di diskriminasi oleh masyarakat setempat. 


\section{Kesimpulan}

Berdasarkan uraian pembahasan dan analisa sebagai hasil penelitian yang berkenaan dengan peraturan bupati nomor 52 Tahun 2016 tentang organisasi dan tata kerja dinas sosial, maka dapat disimpulkan bahwa dalam upaya pemberdayaan penyandang disabilitas, pemerintah dalam hal ini dinas sosial telah melakukan beberapa upaya diantaranya : penyediaan alat bantu disabilitas untuk orang- orang penyandang disabilitas sesuai dengan kebutuhan yang di perlukan dalam tumbuh kembangnya di masyarakat sosial, memberikan bantuan sosial kepada masing- masing penyandang disabilitas, baik yang di dalam panti maupun di luar panti, yaitu berupa bantuan sembako pertahunnya dan pemerintah juga memberikan kesempatan untuk penyandang disabilitas untuk di berangkatkan ke malang, untuk mengikuti pelatihan pembuatan keripik pisang, guna untuk memberikan kesempatan kepada penyandang disabilitas untuk memiliki wira usaha sendiri.

Dari beberapa upaya- upaya yang di lakukan oleh dinas sosial atau yang terlah di paparkan di atas telah berjalan dengan baik, meskipun memiliki hambatan sesuai dengan ketentuan peraturan bupati nomor 52 tahun 2016 tentang organisasi dan tata kerja dinas sosial dan undang- undang yang telah di atur. Ada beberapa faktor yang menyebabkan pelaksanaan upaya dinas sosial terhadap penyandang disabilitas dapat terselesaikan/ sebagai faktor pendukung di antaranya: dukungan dari keluarga mampu membuat penyandang disabilitas tidak merasa sendirian di dalam hidupnya, adanya dorongan yang menyebabkan mereka tidak selalu terpuruk dalam sebuah kekurangan, dan dukungan dari masyarakat juga tidak lain demi untuk menyejahterakan penyandang disabilitas agar terhindar dari kasus deskriminasi terhadap penyandang disabilitas.

Ada beberapa faktor yang menyebabkan pelaksanaan upaya dinas sosial terhadap penyandang disabilitas terhambat diantaranya: kurangnya respon dari keluarga dan masyarakat yang merawat penyandang disabilitas dalam mengajukan permohonan untuk mendapatkan alat bantu disabilitas tersebut bagi anak- anak, dan terbatasnya anggaran pemerintah untuk mengalokasikan dana kedalam penyediaan dan aksesbilitas alat bantuk disabilitas. Dengan terbatasnya anggaran 
pemerintah maka penyediaan dan fasilitas alat disabilitas pun sangat terbatas bagi penyandang disabilitas. Dinas Sosial dalam pemberdayaan bagi penyandang disabilitas ini sebagai suatu kegiatan yang dilakukan berdasarkan tugas pokok dan fungsinya untuk mempengaruhi, mengarahkan dan menggerakkan perilaku penyandang disabilitas untuk bekerja bersama-sama dalam mencapai tujuan yang di kehendaki yakni kemandirian. Pemberdayaan terhadap penyandang disabilitas perlu dilakukan oleh Dinas Sosial guna meningkatkan kemandirian penyandang disabilitas sehingga mereka tidak lagi hanya bergantung pada orang lain.

Dinas Sosial dalam menjalankan suatu upaya dibutuhkan suatu tanggung jawab untuk menjalankan sebuah organisasi sehingga dalam melaksanakan tugas dan fungsinya sebagai pelaksana dan pembinaan dibidang sosial dapat berjalan dengan efektif dan efisien. Meskipun dinas sosial memiliki hambatan dalam menjalankan pemberdayaan bagi penyandang disabilitas namun, dinas sosial tetap pengupayakan yang terbaik untuk penyandang disabilitas. Dari peraturan yang di keluarkan oleh bupati mengenai organisasi dan tatakerja dinas sosial mengenai rehabilitas sosial anak dan lanjut usia, penyandang disabilitas diluar panti dan/ lembaga, pelayanan tuna wisma dan fakir miskin dan, rehabilitas sosial dan korban perdagangan orang. Bahwa, dinas sosial telah melaksanakan tugasnya mengenai rehabilitas sosial anak dan lanjut usia serta penyandang disabilitas di luar panti dan lembaga.

Namun mengenai pelayanan tuna wisma dan fakir miskin serta rehabilitas sosial dan korban perdagangan orang. Belum terlaksana di karenakan mayoritas masyarakat merauke termaksud kedalam golongan menegah ke bawah dalam artian masyarakat kota merauke tidak memiliki masyarakat yang benar- benar menjadi fakir miskin, serta di kabupaten merauke juga belum ada kasus perdagangan orang, sehingga untuk fungsi pelayanan tuna wisma dan fakir miskin serta rehabilitas sosisal dan korban perdagagngan orang dinas sosial tidak/ belum melaksanakan.

\section{Daftar Pustaka}

Abdulsyani. 2002. Sosiologi (skema teori dan terapan). PT. Bumi Aksara; Jakarta.

Anggara, Sahya. 2014. Kebijakan Publik. PUSTAKA STIA: Bandung 
Miles, Mattew B dan Humberman, Michael A. 1992. Analisis Data kualitatif. Univesity IndonesiaPRESS: Jakarta.

Refani. Nur Kholis. 2013 Panduan Anak Berkebutuhan Khusus. Yogyakarta.

Coleridge Peter. 2007. Pembahasan dan Pembangunan, Perjuangan Penyandang Cacat di NegaraNegara Berkembang. Pustaka Pelajar. Yogyakarta.

Undang- Undang Negara Republik Indonesia Tahun 1945

Undang- Umdang Nomor 8 Tahun 2016

Tentang Hak- Hak Penyandang Disabilitas.

Peraturan Bupati Nomor 52 Tahun 2016 Tentang Organisasi dan Tatakerja Dinas Sosial 